\title{
Association of Age-Related Hearing Loss with Cognitive Decline
}

\author{
Juyong Chung \\ Department of Otorhinolaryngology-Head and Neck Surgery, Wonkwang University College of Medicine, Iksan, Korea
}

\section{노화성 난청과 인지기능 저하의 연관성}

정주용

원광대학교 의과대학 이비인후과학교실

\author{
Received March 18, 2020 \\ Revised April 2,2020 \\ Accepted April 6, 2020 \\ Address for correspondence \\ Juyong Chung, MD \\ Department of Otorhinolaryngology- \\ Head and Neck Surgery, \\ Wonkwang University \\ College of Medicine \\ 895 Muwang-ro, Iksan 54538, Korea \\ Tel $+82-63-859-1489$ \\ E-mail claudia7974@naver.com
}

A number of studies have demonstrated a significant association between age-related hearing loss (ARHL) and cognitive decline. However their relationship is not clear. In this review, we focused on the etiological mechanisms between ARHL and cognitive decline to explain the nature of this relationship: 1) causal mechanisms (e.g., cognitive load hypothesis, cascade hypothesis); 2) common cause mechanisms (e.g., microvascular disease); 3) overdiagnosis or harbinger hypothesis. We conclude that no single mechanism is sufficient and hearing and cognition related to each other in several different ways. In addition, we reviewed the effectiveness of hearing intervention (e.g., hearing aids and cochlear implants) on cognition function, and the role of hearing aid use and cochlear implant depends on the relevant mechanism.

Korean J Otorhinolaryngol-Head Neck Surg 2020;63(4):145-53

Key Words Cognition · Hearing aids $\cdot$ Hearing loss $\cdot$ Hypothesis $\cdot$ Relationship.

\section{서 론}

노화성 난청(age-related hearing loss, Presbycusis)은 노 화에 의한 퇴행성 변화로 인해 발생하는 난청으로, 65 세 이 상의 고령에서 발생하는 흔한 만성 질환이다. 전형적인 특징 으로는 서서히 진행하는 양측의 대칭적인 청력저하가 주로 고주파수 영역에 나타나는 것이다.) 난청과 인지기능 저하가 노화현상과 관련된다는 것은 잘 알려져 있다. 난청과 인지기 능 저하와의 독립적 연관성은 노화성 난청이 치매의 원인이 될 수 있다는 가설이 제시되면서 30년 전 처음 보고되었다.2) 그동안 이비인후과 전문의와 신경과 전문의, 그리고 역학자 들과 인지과학자들의 교류가 적어서 그 관련성에 대한 연구 가 부족했다. 그러나 최근에 이에 대한 연구가 활발해지고 있고 많은 체계적 리뷰 및 메타 분석에 대한 논문에서 노화

This is an Open Access article distributed under the terms of the Creative Commons Attribution Non-Commercial License (https://creativecommons.org/licenses/by-nc/4.0) which permits unrestricted non-commercial use, distribution, and reproduction in any medium, provided the original work is properly cited.
성 난청과 인지기능 저하 및 치매 위험의 증가 등에 관한 연 관성을 보여주고 있다. ${ }^{3-5)}$ Loughrey 등근 20264 명을 대상으 로 한 36개의 연구들을 메타 분석하여 노화성 난청과 인지기 능 저하 및 치매에 대한 연관성을 분석하였고, 노화성 난청과 인지기능 저하[odds ratio(OR), 1.22; 95\% confidence interval(CI), 1.09 1.36]와 치매[OR, 1.28; 95\% CI, 1.02 1.59] 와의 유효한 연관성을 확인하였다. 또한 치매에 대한 9 가지 건강 및 생활습관 요인 중, 난청은 가장 큰 잠재력을 지닌 수 정 가능한 위험 요소로 뽑혔다.) 그러나 아직 노화성 난청과 인지기능 저하의 관련성에 대한 원인 메커니즘은 명확히 밝 혀지지 않았다.

본 연구에서는 노화성 난청과 인지기능 저하의 연관성 및 원인 메커니즘을 최근 논문 리뷰를 통해 정리하고, 나아가 청 각적 중재가 인지기능에 있어 어떤 영향을 미칠지에 대해 알 아보고자 한다. 


\section{본 론}

\section{노화성 난청과 인지기능 저하의 관련성}

노화성 난청과 인지 기능 저하의 관련성을 보여주는 많은 연구들이 있는데, 주로 노화성 난청에 이환된 경우 치매발생 위험이 증가할 수 있다는 것이다. Lin 등근 $25 \mathrm{~dB} \mathrm{HL}$ 이상 의 난청이 있는 경우 청력역치가 $10 \mathrm{~dB}$ 씩 증가함에 따라 치 매 발생 위험이 20\%씩 증가한다고 보고했다. 최근에 Gurgel 등 ${ }^{8}$ 은 65 세 이상의 노인에서 청력이 정상인 경우 치매로 이 환되는데 걸리는 시간이 11.9 년인데 반해, 난청이 있는 경우 에는 10.3 년이 걸린다고 보고하였다. 게다가 몇 가지 인지 검 사 점수가 난청의 증가 정도에 따라 선형으로 감소한다는 보 고들도 있다.9) 노인들에서 심도 난청과 낮은 기억력 및 실행 능력 사이의 유효한 연관성이 언어적, 비언어적 인지기능 평 가를 통해 밝혀졌다. ${ }^{10-13)}$

이렇듯 노화성 난청은 인지 기능 저하 및 치매 발생과 독립 적으로 연관된다고 할 수 있다. 특히 청력이 정상인 경우에 비 해, 경도, 중등도, 심도 난청이 있는 경우에 치매 발생 위험이 각각 2 배, 3 배, 5 배 이상 증가한다. ${ }^{14,15)}$ 이렇게 난청이 치매 발 생의 위험요인으로 여겨지게 된 것은 최근의 일이며, 최근의 전향적 코호트 연구에서 난청이 독립적인 치매 발생의 위험 요인임을 보여주고 있다.7, ${ }^{7,16,17)}$ 개체군 귀소분획(population attributable fraction, $\mathrm{PAF}$ )이란 주어진 기간 동안 난청과 같 은 위험 요인이 제거되었을 때, 치매 발생이 감소하는 비율을 나타내며, 치매 발생에서 난청의 PAF는 $23.0 \%$ 로 이는, 우울 (10.1\%), 사회적 고립(5.9\%), 흡연(13.9\%), 고혈압(5.1\%), 당뇨 (3.2\%) 등의 다른 위험요인들보다 가장 높은 수치이다. ${ }^{6}$ 이렇 듯 난청이 치매 발생에 있어 높은 위험률을 가지며, 그 발생 률이 노인에게서 높고, 쉽게 진단할 수 있고, 보청기 같은 청 각적 중재로 치료 가능하다는 점에서 치매의 예방을 위한 타 겟으로 삼을 수 있다. 그러나 그 전에 노화성 난청과 치매 사 이의 정확한 인과관계 정립이 필요할 것이다.

이뿐만 아니라, 노인에게서 난청은 건강한 노년을 위한 삶 과 관련된 많은 영역인 사회 참여, 신체 이동성, 활동성, 낙상, 활력, 치매 등에 영향을 미치게 된다., ${ }^{2,1,19)}$ 중등도 이상의 난 청을 가진 경우에 정상 성인에 비해 더 낮은 신체 활동성을 가지는데 이는 사회적 고립 때문이다. 청각장애는 인지적 과 부하를 일으켜서 자세나 균형을 유지하는데 중요한 주의력과 인지력에 영향을 미치게 된다. 청각장애가 청각적 환경을 효 과적으로 모니터하고 파악하는데 제한을 일으켜서 신체적 활동 수행에 영향을 미치게 된다. 또는 청력과 신체적 활동에 동시에 영향을 미치는 공통적 병리기전이 있다고도 할 수 있 다. 즉, 심혈관 질환은 난청 뿐 아니라 건강악화와 신체활동
저하를 일으킨다. ${ }^{20}$ 공통의 신경학적 퇴행이 와우와 균형유 지에 필수적인 전정기관에 영향을 미친다고 할 수 있으며 이 는 난청과 신체 활동 저하의 관련성을 설명할 수 있다.

\section{노화성 난청과 인지기능 저하의 연관성에 대한 가능한 메커니즘}

\section{Causal mechanism}

이는 노화성 난청에 의해 인지기능 저하가 발생한다는 것 으로, 이 둘의 관계가 인과관계라는 가설이다. 노화성 난청이 치매에 기여할 수 있음을 보여주는 몇 가지 잠재적인 원인 가 설이 있다(Fig. 1). 이에 대해 가능한 가설로는 Cognitive load hypothesis와 Cascade hypothesis 등이 있다.

\section{Cognitive load hypothesis}

이 가설은 교육심리학에서 기원한 것으로 1998년 John Sweller라는 심리학자에 의해 고안된 것이다. 인지의 부하 (cognitive load)란 작업 수행을 위해 개인이 필요로 하는 인 지적 노력이나 처리해야 할 정보의 양이다. 즉, 난청을 가진 사람들에게 청취 노력(listening effort)은 언어를 이해하기 위한 주의 및 집중을 말하며, 이런 노력을 항상 기울여야 한 다. 난청은 청각 신호의 감소를 일으키고, 청각 인지 과정을 위해 더 많은 인지 자원을 필요로 하고, 다른 인지 과제에 사 용되는 자원을 청취노력 쪽으로 전환하게 되어, 결국 인지적 예비율(cognitive reserve) 감소를 유발한다는 가설이다. ${ }^{21-24)}$ 일상 생활에서 청각 지각 처리에 쏟는 과도한 인지 부하가 뇌 의 구조적 변화와 다른 인지 과정의 손상과 관련된 신경의 퇴 행을 유발할 수 있다. 이후에 청각적 지각에 이용할 수 있는 인지적 자원을 감소시켜 난청을 심화시키고 언어 이해를 감 소시키는 악순환이 발생하게 되어 난청 환자에서 인지적 부 하는 작업기억과 같은 다른 인지과정으로부터 인지자원을 청각 지각 쪽으로 전환시킨다는 것이다. 이론적으로, 이것이 인지기능 저하를 일으키게 된다. ${ }^{25)}$

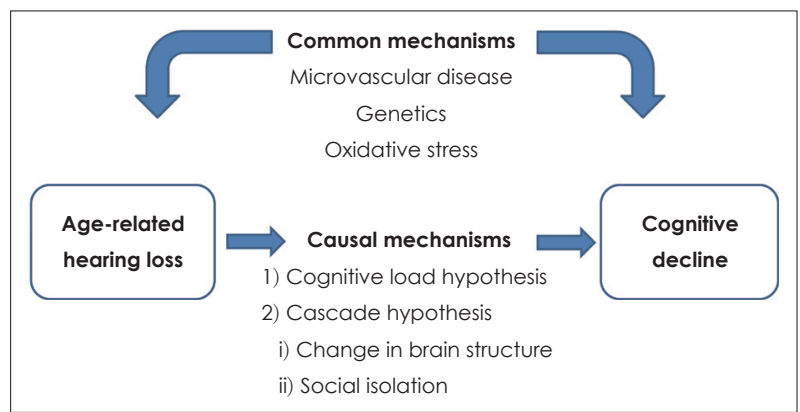

Fig. 1. Conceptual model of the association of age-related hearing loss with cognitive decline. 
Cascade hypothesis

Changes in brain structure

또 다른 가설은 노화성 난청이 뇌 구조에 변화를 일으키 고 치매 위험을 증가시킨다는 것이다. 몇몇 단면 연구들에서 난청을 가진 노인들의 MRI에서 일차 청각 피질의 부피 감소 를 보였고, 이는 감소된 청각 신호에 의한 만성적인 청각 피질 활성화의 감소 때문일 것이다. ${ }^{26,27)}$ 노화성 난청과 뇌부피 감 소에 대한 126 명을 대상으로 한 6.4 년 간의 추적 연구에서 정상 청력군에 비해 난청군에서 뇌부피의 큰 감소율을 보였 다. 또한, 그 크기는 정상군과 경도 인지 장애군 간의 보이는 뇌 위축율의 차이와 같았다. ${ }^{28,29)}$

노화성 난청을 가진 노인에서 뇌부피의 감소를 보이는 부 위는 뇌 전체 뿐만 아니라 우측 측두엽이며, 이 부위는 구어 처리 및 기억, 감각통합, 초기 인지장애, 초기 알츠하이머 치 매에서 중요한 부위이다. ${ }^{30)}$ 따라서 청각 처리과정을 담당하는 부위의 뇌부피 감소는 잠재적으로 치매 위험 증가를 유발할 수 있는 인지 과정에 예상치 못한 영향을 미칠 수 있다. 뇌는 환경 자극과 학습에 반응하여 변할 수 있는 능력인 신경가소 성(neuroplasticity)을 가지고 있다. ${ }^{31)}$ 용불용설의 이론이 청각 신호 처리과정에도 적용되는데 듣고 그것을 처리하는 능력을 계속 사용하지 않으면 그 능력을 잃을 수 있는 것이다. 노인 들에게 청력의 악화는 청각피질의 회백질(white mater)을 줄 이는데 인과적 역할을 한다고 볼 수 있다. ${ }^{26}$

\section{Social isolation}

노화성 난청과 인지 기능 저하를 설명하는 또 다른 가설은 사회적 고립이다. 노화성 난청 환자에서의 의사소통의 실패 는 사회적 통합을 심각하게 제한하며, 이런 사회화의 감소는 사회적 고립, 고독감과 우울증을 일으키게 된다. ${ }^{32-37)}$ 연구에 따르면 사회적 고립이 전반적 인지 수행의 저하, 빠른 인지 감 소, 실행 기능 저하, 부정성 증가, 우울 인지에 대한 위험요소 인 것으로 나타났다. ${ }^{38)}$ 또한, 부족한 사회적 네트워크 및 사회 적 지지의 감소, 고독감이 건강한 사람에게서 치매의 위험을 증가시키는 것으로 보고되고 있다. ${ }^{39)}$ 즉, 우울증과 사회적 고 립은 청각 장애와 인지 장애 사이를 매개하는 역할을 하며 청각장애와 관련된 이러한 문제는 직간접적으로 인지장애로 이어질 수 있다.

\section{Common mechanism; common cause hypothesis}

Common mechanism 가설은 노화성 난청 그 자체가 치매 를 일으키는 것이 아니라, 치매와 노화성 난청에 기여하는 공 통 메커니즘이 있다는 것이다. 이 가설에 따르면 난청과 인지
장애는 뇌의 노화과정에서 공통적인 신경퇴화 과정의 결과 라고 할 수 있다. ${ }^{21)}$ 즉, 노화성 난청과 인지 기능 저하가 원인 관계가 아니라 공통의 원인에 의해 발생하고 서로 독립적으 로 발생한다는 것이다. ${ }^{25)}$

가설에 따르면 감각적 예민함(sensory acuity)은 노화하는 뇌의 생리적 무결성(physiological integrity)을 반영하는 지 표라 할 수 있다. ${ }^{40)}$ 노화성 난청의 발생과정에서 다양한 기능 적이고 구조적인 변화가 말초와 중추 기관에서 발생하게 된 다. 이러한 변화는 혈관조의 변성, 유모세포와 일차 구심 신 경의 감소, 와우핵 신경원 감소와 같은 중추 청각 경로의 변 화, 신경전달물질 분비의 변화 등이 있다. ${ }^{41)}$

노화성 난청에서는 다양한 정도로 말초 및 중추 청각 경로 에서 병리학적 변화가 복합적으로 일어나게 된다. 노화성 난 청과 치매는 복합적인 원인으로 발생하며 가장 흔한 원인으 로 미세순환 부전, 전신적인 신체건강상태, 유전, 산화 스트 레스 등이 있다.

심혈관계 질환과 뇌혈관 질환은 치매의 위험요인으로 잘 알려져 있다. ${ }^{6,42}$ 뇌졸증과 뇌경색 등의 뇌혈관 손상은 혈관성 치매를 일으킬 뿐 아니라 알츠하이머병을 가진 노인들에게 더 자주 발생한다. 게다가, 인구기반 조사에서 중등도 및 고 도 난청과 뇌졸증 사이의 유의한 연관성이 노인층에서 관찰 되었다. ${ }^{43)}$ 대뇌의 미세혈관 질환이 뇌에 대한 혈액 공급 감소 와 산소, 포도당, 그리고 다른 영양소의 부적절한 공급을 통 해 인지 기능을 저하시키고 심지어 치매 발달에 기여할 수 있 는 것처럼, ${ }^{44,45}$ 미세 혈관 질환은 내이에도 허혈성 손상을 일 으켜서 와우의 혈액 순환 부전을 야기할 수 있다. ${ }^{46)}$ 따라서 동맥경화, 흡연, 당뇨와 같은 혈관질환의 위험요인이 청력과 인지기능 둘 다에 영향을 미친다고 할 수 있다. ${ }^{620,47,48)}$ Apolipoprotein $\mathrm{E}(\mathrm{APOE})$ 는 퇴행성 신경질환과 강하게 연관되는 유전자로 알려져 있는데, 알츠하이머 치매를 유발하기 쉬운 $\mathrm{APOE} \varepsilon 4$ allele은 또한 난청과도 연관됨이 보고되고 있다. ${ }^{49-51)}$ 즉, 85세의 고령환자들에서 APOE\&4 allele을 가진 경우 난 청의 위험도가 2 배 이상 증가했다고 보고하고 있다. ${ }^{49)}$

뇌는 다양한 신호전달 역할을 수행하기 위해 화학적으로 다양한 반응기전을 가지기 때문에 산화적 스트레스에 민감 하다. ${ }^{52)}$ 또한 많은 연구에서 밝혀진 바와 같이, 활성 산소가 청각 처리과정에서 미세순환에 있어 중요한 역할을 하며, 미 토콘트리아 DNA 결손과 이어지는 세포 사멸과정이 내이와 중추 청각 경로의 병태생리에 있어 중요한 역할을 한다고 할 수 있다. ${ }^{41,53-55)}$

\section{Overdiagnosis or harbinger hypothesis}

난청과 인지 기능 저하 사이의 연관성을 설명하는 또 다른 
가능한 메커니즘은 과잉 진단(overdiagnosis)이며, 인지기능 보다는 청력 감소가 특정 신경심리학적 검사 수행에 영향을 미치는 경우이다. 청력 감소가 인지기능 장애의 정도를 과대 평가 할 수 있다는 축적된 증거들이 있다. ${ }^{56,57)}$ 청력에 의존하 는 언어적 지시나 과제가 인지 기능 평가 동안 사용되기 때문 에, 청력저하가 있는 경우에 불리하게 작용하게 된다. 언어능 력을 많이 요하는 인지 기능 검사의 선택은 난청이 있는 경우 에 적절하지 않지만, 비언어적으로 측정하는 검사일지라도 청 각장애가 있으면 검사에 대한 지침이 복잡해서 인식하기 어 려울 수 있다. 난청은 어느정도 신경심리학적 평가에 있어 기 능적으로 검사 수행에 영향을 미칠 수 있다. ${ }^{58)}$ 한 연구에서 난청이 간이정신상태검사(Mini-Mental State Examination, $\mathrm{MMSE}$ )에 미치는 영향에 대해 인지기능이 정상인 젊은 환자 를 대상으로 연구하였고, 감소된 청력이 MMSE 수행에 유의 하게 영향을 미치고, 따라서 난청의 정도가 치매 진단에 영향 을 미칠 수 있음을 보여주었다. ${ }^{57)}$ 청력 장애가 있는 경우에 인 지 기능이 정상임에도 불구하고, 인지기능 장애로 과진단 되 거나 오진되는 경우가 있을 수 있다.

다른 한편으로는, 중추청각처리 장애로 인한 청력저하는 증상이 나타나기 전의 알츠하이머 치매의 전조(harbinger)로 여겨질 수 있다. ${ }^{59-61)}$ 최근 연구에서 말초와 중추 청각 시스템 의 기능저하가 알츠하이머 치매의 전단계나 초기단계에서 나 타난다고 보고하고 있다. 중추 청각 기능저하로 나타나는 청 력저하를 양분 청취 과제(dichotic listening task)를 통해 평 가하는데, 이는 알츠하이머 치매의 전조(harbinger)가 된다. 초기 단계의 인지기능저하는 난청으로 여겨지는 증상 뒤에 숨 겨질 수 있다. 따라서, 난청에 대한 스크리닝, 특히 위험이 있 는 군에서 중추 청각 테스트는 알츠하이머 치매의 전구단계 를 확인할 수 있는 저렴하고 효과적인 수단으로 추천된다. ${ }^{61,62)}$

\section{New conceptual model of frailty}

노화성 난청과 인지기능 저하 사이의 연관성을 설명하기 위해 최근 노쇠(frailty)와 관련된 가설이 제기되고 있다. ${ }^{63,64)}$ Frailty란 다음의 3 가지 이상의 증상(의도치 않은 체중 감소, 탈진, 무력감, 느린 걸음 속도, 낮은 신체 활동)을 동반하는 임상적 증후군을 말한다. ${ }^{65)}$ 또한 frailty는 낙상, 장애, 잦은 입원, 요양시설입소, 사망 등의 위험을 높인다고 보고하고 있 다. ${ }^{64)}$ 게다가 최근의 인구기반 연구에서는 노화성 난청이 frailty 발생 위험을 높인다고 보고하고 있다. ${ }^{66)}$ 난청이 있는 노인의 경우, frailty의 발생 위험이 $63 \%$ 까지 증가하고 노화 성 난청이 낙상의 높은 위험과 관련되는 frailty의 독립적인 위험 요인으로 작용함을 보여주고 있다. ${ }^{67)}$ 게다가 노화성 난 청이 신체 활동 및 느린 걸음 속도와 낙상 등과 같은 frailty와
관련된 건강 요소와 관련됨이 보고 되었다. ${ }^{68,69)}$ 그리고, frailty는 인지기능 장애 및 치매와도 관련됨이 보고되고 있다. ${ }^{70-72)}$ 따라서, 노화성 난청은 frailty의 중요한 지표가 되며, frailty 자체가 직접적으로 인지기능 저하의 결정요소가 되기도 하고, 의사소통 저하 및 그에 따르는 사회적 고립과 외로움, 그리고 우울증과 같은 부수적인 요소들을 통해 간접적으로 결정 요 인이 되기도 한다(Fig. 2). ${ }^{73)}$

노화성 난청과 사회적 고립은 높은 연관성을 가지며, 그 연관성은 남자보다는 여자에게서 더 높게 나타난다. ${ }^{74)}$ 노화성 난청은 우울증, 불안, 스트레스 등과도 밀접히 관련된다. ${ }^{75)}$ 그 리고 우울증이 치매나 알츠하이머병의 초기 징후로 여겨지기 도 한다. ${ }^{76)}$ 또한 많은 연구들에서 우울증이 노화 과정을 가속 화시켜서 심혈관 질환이나 인지기능 장애와 같은 노화관련 질병위험을 증가시킨다고 보고하고 있다. ${ }^{33,77,78)}$ 우울증과 frailty 간의 양방향성의 연관성도 보고되고 있다. ${ }^{79}$

앞의 연구들을 바탕으로 노화성 난청과 인지기능 저하, 더 나아가 치매와의 관계를 사회적 고립, 우울증, frailty와 같은 중간 매개체를 통해 확립해 보고자 하였다(Fig. 2). 즉, 노화 성 난청은 우울증과 frailty의 위험을 증가시키고, 순차적으로 연관성을 갖는 인지기능 저하와 치매의 위험을 증가시키게 된다. 노화성 난청은 이 conceptual model에서 사회적 고립, 우울증, frailty, 인지기능 저하의 일차적인 개선 가능한 위험 요인이 되기 때문에, 보청기와 같은 청각적 중재가 인지기능 저하 및 치매와 관련된 결과를 상당히 개선시킬 것이라 예상 된다. 그러나 이 모델이 노화성 난청을 치료하는 것이 노인들 에게서 인지 기능 향상에 도움이 될 수 있을 것이라는 근거 를 제공하지만, 아직은 정확한 인과관계의 확립을 위해 많은 후속 연구들이 필요할 것으로 사료된다.

\section{인지기능 개선을 위한 보청기 및 인공와우의 효과}

보청기나 인공와우가 청력이 손상된 노인들에게 인지기능

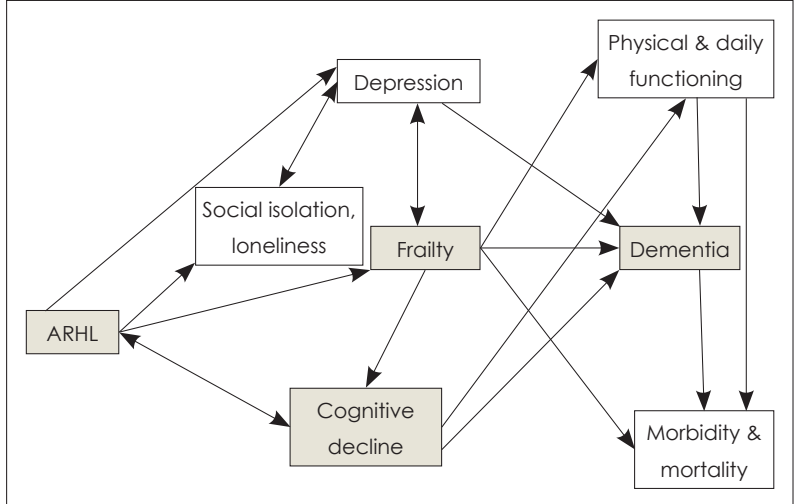

Fig. 2. Conceptual model of frailty. The diagram shows the directional association between age-related hearing loss (ARHL), frailty, cognitive decline, and dementia. 
을 향상 시키는데 기여할 것인가에 대한 의문은 오래전부터 제기되었만, 이를 증명하기는 쉽지 않다. 보청기 같은 청각적 중재가 인지기능에 미치는 영향을 입증하는 증거는 제한적이 고 일관성이 없기 때문에 앞으로 이 문제를 해결하기 위해 후 속 연구들이 필요할 것이다.
보청기가 인지 기능에 미치는 영향에 대해 무작위대조시험 (randomized controlled trial)을 수행한 몇 가지 연구들이 있다. Mulrow 등 ${ }^{80)}$ 은 4 개월간 188 명의 난청환자들을 보청기 착용군과 미착용군으로 나눠서 연구했고, 보청기를 착용한 군에서 작지만 유의한 인지 능력의 향상을 보고했다. 그러나,
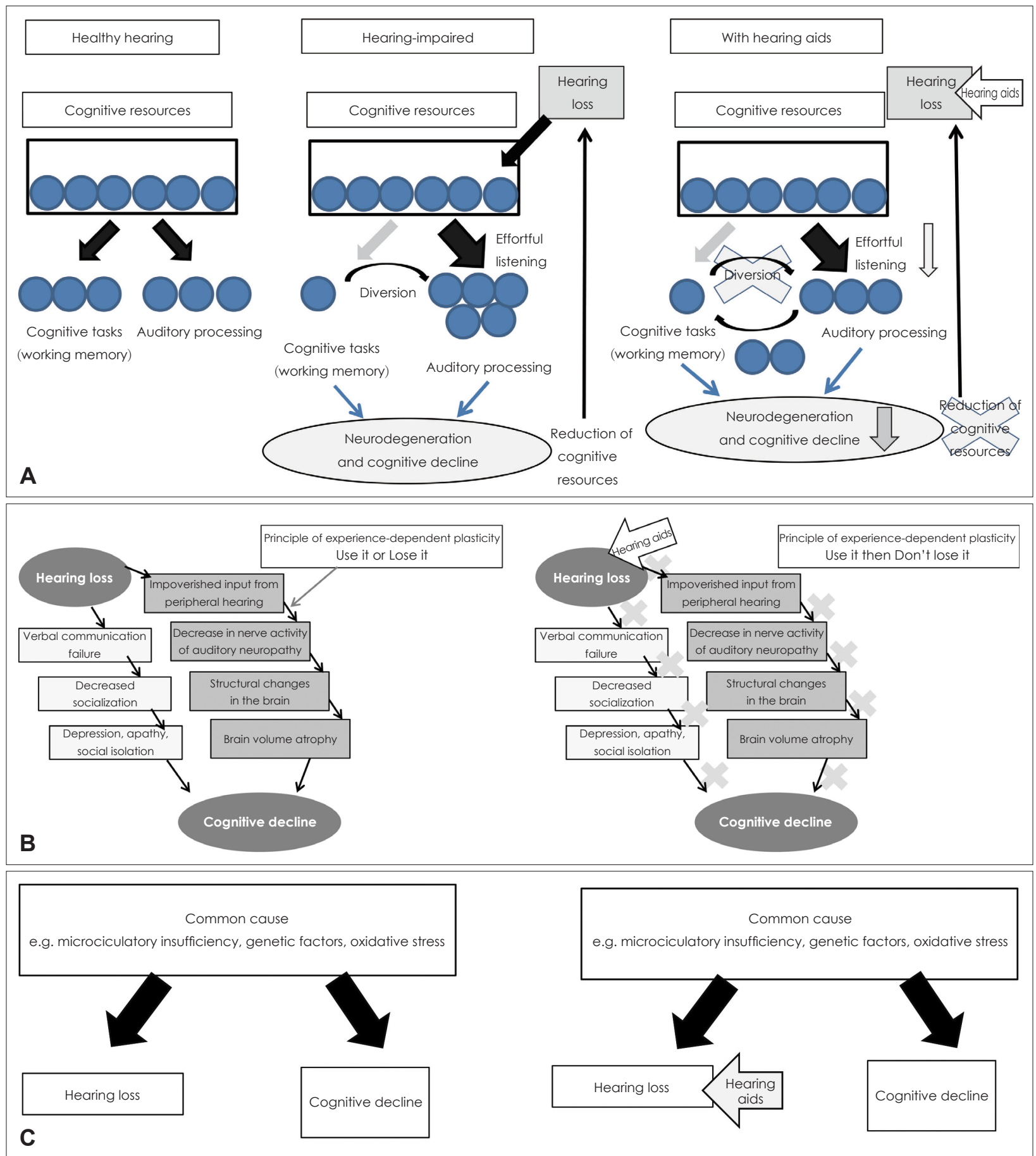

Fig. 3. The etiological mechanisms between $A R H L$ and cognitive decline and the effectiveness of intervention with hearing aids on cognitive function. Cognitive Load Hypothesis (A). Cascade Hypothesis (B). Common Cause Hypothesis (C). Overdiagnosis or Harbinger Hypothesis (D); Area a: Overdiagnosis of cognitive decline due to the effects of hearing loss, Area b: Hearing loss manifested as a central auditory dysfunction can be a harbinger of Alzheimer dementia. 


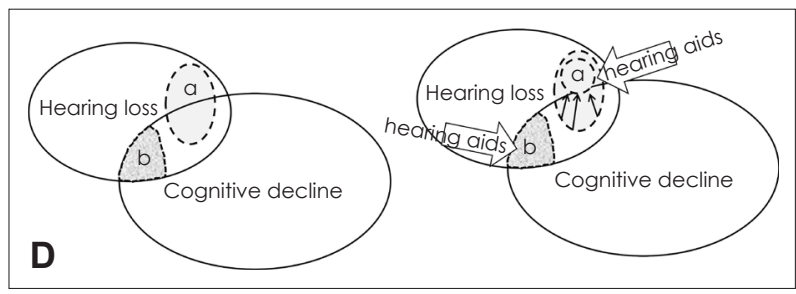

Fig. 3. The etiological mechanisms between ARHL and cognitive decline and the effectiveness of intervention with hearing aids on cognitive function. (A) Cognitive Load Hypothesis. (B) Cascade Hypothesis. (C) Common Cause Hypothesis. (D) Overdiagnosis or Harbinger Hypothesis; Area a: Overdiagnosis of cognitive decline due to the effects of hearing loss, Area $b$ : Hearing loss manifested as a central auditory dysfunction can be a harbinger of Alzheimer dementia (continued).

보청기의 인지기능 향상의 효과에 대해 다기관 이중 맹검검 사가 65세 이상 알츠하이머 치매환자 51명에서 수행되었고, 6개월후 알츠하이머병 평가척도(Alzheimer's disease assessment scale-cognitive subscale)에서 보청기 착용 후에도 유의한 변화를 보이지 않음이 보고되기도 하였다. ${ }^{81}$

프랑스에서 10 개의 3 차 의료기관에서 수행한 전향적 연구 에서 65세에서 85세의 94명 환자에서 인공와우 수술 전, 수 술 후 6개월, 12 개월 후 인지기능을 평가하였다. ${ }^{82)}$ 수술 전 낮 은 인지 기능 점수를 받은 환자들의 $80 \%$ 이상에서 인공와우 수술 후 12 개월째 인지 기능의 향상을 보였고 인공와우를 통 한 청각적 재활이 노인들에게 손상된 인지기능의 개선과 관 련이 있다는 결론을 내었다. 최근의 또 다른 연구는 보청기와 인공와우가 정신 건강측면에서의 삶의 질을 향상시킨다고 보 고하고 있다. ${ }^{83)}$ 특히 인공와우가 보청기에 비해 6개월, 12 개월 째 사용 후 2 배나 정신적 측면의 점수를 향상시켰다고 보고 되었다. Di Nardo 등 ${ }^{84)}$ 은 60세 이전에 인공와우를 시행한 환 자와 60세 이상 환자들 간의 청각 수행력과 몇 가지 삶의 질 결과를 비교했다. 60 세 이전에 인공와우를 시행 받은 환자들 이 언어평가에서 유의하게 우수했지만, 고령의 인공와우 환 자들도 수술 전에 비해 언어 평가에서 유의한 향상을 보였다. 또한 신체적 및 정신적 건강 척도, 외부인과 대화, TV나 전화 의 사용 등에서 정상인들과도 유의한 차이가 없었다. 흥미로 운 것은 인공와우 수술에서의 전반적 만족도는 젊은 연령에 비해 고령환자들에서 더 높았다. 고령 인공와우 환자들에서 이런 높은 만족도와 삶의 질과 의사소통 능력의 극적인 향상 은 청각 인식의 향상만으로는 설명할 수는 없다. 따라서 인공 와우를 이용한 청각적 재활과 인지기능 향상과의 관계를 입 증하기 위한 더 많은 연구들이 필요할 것이다.

이전의 연구결과들은 일관되지 않았고 많은 역학적 연구 들이 청력장애가 인지기능 저하와 밀접하게 연관됨을 보여주 었지만 보청기 사용이 왜 인지기능 저하를 예방할 수 있을지 에 대해 논리적으로 증명하는 것은 아직 어렵고 명확하지 않
다. 앞에서 살펴 본 각각의 가설에서 원인 메커니즘을 고려해 서 청각적 중재가 인지기능 향상에 어떤 영향을 미칠지에 대 해 Fig. 3에서 볼 수 있다.

만약 congnitive load hypothesis가 맞다면, 보청기 사용은 청각처리과정에서 필요한 노력을 줄일 수 있고, 불필요한 인 지 수행으로 인지 자원을 전환시켜 뇌위축 과정을 막고 인지 자원을 유지시킬 수 있다(Fig. 3A). 만약 cascade hypothesis 가 유효하다면, 말초로부터 들어오는 지속적인 입력은 보청 기를 사용함으로써 유지되게 된다. 경험 중심의 가소성에 의 거하면, 구조적이고 기능적인 뇌의 재구성 능력은 성인의 성 숙한 뇌일지라도 외부나 내부 환경 변화에 적응하게 된다. ${ }^{85)}$ 보청기 사용으로 인한 의사소통 능력의 회복이 사회적 교류 향상을 돕게 된다(Fig. 3B). 강한 사회적 유대감을 유지시키 는 것이 인지기능 저하를 막고 치매의 발생을 지연시킬 수 있 다는 보고가 있다. ${ }^{86)} \mathrm{Hsiao}$ 등 $^{87)}$ 은 알츠하이머 치매의 동물 모델에서 인지 결핍에 있어 사회적 활동의 중요성을 연구했고, 사회적 고립이 인지기능장애를 가속화시키고 동년배들과의 사회적 교류가 알츠하이머 치매 관련 기억력 장애를 어떻게 구제할 수 있는지를 보여주었다. 만약 common cause hypothesis가 맞다면, 인지 기능 장애는 청각적 중재와는 아무 런 관련없이 진행될 것이다. 청각 장애를 감소시키는데 보청 기가 매우 효과적일지라도, 인지장애를 예방하는 데는 기여 하지 못할 것이다(Fig. 3C). Overdiagnosis hypothesis에서 는 보청기 사용이 정확한 신경심리학 검사 수행을 가능하게 하고 과잉진단이나 오진의 가능성을 줄일 수 있다고 하였다 (Fig. 3D). Harbinger hypothesis에서는 청각적 중재가 치매 발생을 지연시킬 수 있을 지에 대해서는 좀 더 연구가 필요할 것이다. 따라서 노화성 난청과 인지 기능 저하에 대한 메커니 즘에 따라서 청각적 중재가 인지 기능 향상에 미칠 영향은 다양한 양상으로 복잡하게 나타난다.

\section{결 론}

노화성 난청과 인지 기능 저하의 높은 관련성은 여러 논문 들을 통해 알 수 있다. 그러나 이 둘의 관계가 노화성 난청이 인지 기능 저하를 일으키는 원인인지, 아니면 공통의 원인에 의해 노화성 난청과 인지 기능 저하가 동시에 발생되는지는 아직 논란의 여지가 많지만, 아마도 복합적인 요인들이 관여 하는 서로 높은 관련성을 갖는 관계일 것으로 사료된다. 또 한, 노화성 난청은 인지기능 저하 및 치매의 중요한 위험요인 으로 작용하기 때문에, 치매의 예방을 위해서 보청기나 인공 와우 등을 통한 청각적 재활의 중요성이 강조되는 것이다. 따 라서, 잘 듣는 것의 중요성에 대한 사회적 계몽이 필요하며, 
인지 기능 저하의 위험성 있는 환자들에게 청력 스크리닝의 필요성에 대해 알리는 것 또한 중요한 일일 것이다.

\section{Acknowledgments}

This research was supported by Basic Science Research Program through the National Research Foundation of Korea (NRF) funded by the Ministry of Education (Grant no. NRF-2017R1D1A3B03034486 to Juyong Chung).

\section{ORCID}

Juyong Chung

https://orcid.org/0000-0001-5099-5243

\section{REFERENCES}

1) Fetoni AR, Picciotti PM, Paludetti G, Troiani D. Pathogenesis of presbycusis in animal models: A review. Exp Gerontol 2011;46(6): 413-25.

2) Uhlmann RF, Larson EB, Rees TS, Koepsell TD, Duckert LG. Relationship of hearing impairment to dementia and cognitive dysfunction in older adults. JAMA 1989;261(13):1916-9.

3) Loughrey DG, Kelly ME, Kelley GA, Brennan S, Lawlor BA. Association of age-related hearing loss with cognitive function, cognitive impairment, and dementia: A systematic review and meta-analysis. JAMA Otolaryngol Head Neck Surg 2018;144(2): 115-26.

4) Wei J, Hu Y, Zhang L, Hao Q, Yang R, Lu H, et al. Hearing impairment, mild cognitive impairment, and dementia: A metaanalysis of cohort studies. Dement Geriatr Cogn Dis Extra 2017; 7(3):440-52.

5) Ford AH, Hankey GJ, Yeap BB, Golledge J, Flicker L, Almeida OP. Hearing loss and the risk of dementia in later life. Maturitas 2018;112:1-11.

6) Livingston G, Sommerlad A, Orgeta V, Costafreda SG, Huntley J, Ames D, et al. Dementia prevention, intervention, and care. Lancet 2017;390(10113):2673-734.

7) Lin FR, Metter EJ, O’Brien RJ, Resnick SM, Zonderman AB, Ferrucci L. Hearing loss and incident dementia. Arch Neurol 2011; 68(2):214-20.

8) Gurgel RK, Ward PD, Schwartz S, Norton MC, Foster NL, Tschanz JT. Relationship of hearing loss and dementia: A prospective, population-based study. Otol Neurotol 2014;35(5):775-81.

9) Lin FR, Ferrucci L, Metter EJ, An Y, Zonderman AB, Resnick SM. Hearing loss and cognition in the baltimore longitudinal study of aging. Neuropsychology 2011;25(6):763-70.

10) Ohta RJ, Carlin MF, Harmon BM. Auditory acuity and performance on the mental status questionnaire in the elderly. J Am Geriatr Soc 1981;29(10):476-8.

11) Tay T, Wang JJ, Kifley A, Lindley R, Newall P, Mitchell P. Sensory and cognitive association in older persons: Findings from an older Australian population. Gerontology 2006;52(6):386-94.

12) Thomas PD, Hunt WC, Garry PJ, Hood RB, Goodwin JM, Goodwin JS. Hearing acuity in a healthy elderly population: Effects on emotional, cognitive, and social status. J Gerontol 1983;38(3):321-5.

13) Gennis V, Garry PJ, Haaland KY, Yeo RA, Goodwin JS. Hearing and cognition in the elderly. New findings and a review of the literature. Arch Intern Med 1991;151(11):2259-64.

14) Lin FR, Yaffe K, Xia J, Xue QL, Harris TB, Purchase-Helzner E, et al. Hearing loss and cognitive decline in older adults. JAMA Intern Med 2013;173(4):293-9

15) Foster SM, Davis HP, Kisley MA. Brain responses to emotional images related to cognitive ability in older adults. Psychol Aging 2013;28(1):179-90.

16) Quaranta N, Coppola F, Casulli M, Barulli MR, Panza F, Tortelli R, et al. The prevalence of peripheral and central hearing impairment and its relation to cognition in older adults. Audiol Neurootol 2014; 19 Suppl 1:10-4.

17) Golub JS, Luchsinger JA, Manly JJ, Stern Y, Mayeux R, Schupf N. Observed hearing loss and incident dementia in a multiethnic cohort. J Am Geriatr Soc 2017;65(8):1691-7.

18) Cacciatore F, Napoli C, Abete P, Marciano E, Triassi M, Rengo F. Quality of life determinants and hearing function in an elderly population: Osservatorio Geriatrico Campano Study Group. Gerontology 1999;45(6):323-8.

19) Ives DG, Bonino P, Traven ND, Kuller LH. Characteristics and comorbidities of rural older adults with hearing impairment. J Am Geriatr Soc 1995;43(7):803-6.

20) Gates GA, Cobb JL, D'Agostino RB, Wolf PA. The relation of hearing in the elderly to the presence of cardiovascular disease and cardiovascular risk factors. Arch Otolaryngol Head Neck Surg 1993;119(2):156-61.

21) Wayne RV, Johnsrude IS. A review of causal mechanisms underlying the link between age-related hearing loss and cognitive decline. Ageing Res Rev 2015;23(Pt B):154-66.

22) Tun PA, McCoy S, Wingfield A. Aging, hearing acuity, and the attentional costs of effortful listening. Psychol Aging 2009;24(3): 761-6.

23) Martini A, Castiglione A, Bovo R, Vallesi A, Gabelli C. Aging, cognitive load, dementia and hearing loss. Audiol Neurootol 2014; 19 Suppl 1:2-5.

24) Chern A, Golub JS. Age-related hearing loss and dementia. Alzheimer Dis Assoc Disord 2019;33(3):285-90.

25) Uchida Y, Sugiura S, Nishita Y, Saji N, Sone M, Ueda H. Agerelated hearing loss and cognitive decline - the potential mechanisms linking the two. Auris Nasus Larynx 2019;46(1):1-9.

26) Peelle JE, Troiani V, Grossman M, Wingfield A. Hearing loss in older adults affects neural systems supporting speech comprehension. J Neurosci 2011;31(35):12638-43.

27) Eckert MA, Cute SL, Vaden KI Jr, Kuchinsky SE, Dubno JR. Auditory cortex signs of age-related hearing loss. J Assoc Res Otolaryngol 2012;13(5):703-13.

28) Lin FR, Ferrucci L, An Y, Goh JO, Doshi J, Metter EJ, et al. Association of hearing impairment with brain volume changes in older adults. Neuroimage 2014;90:84-92.

29) Driscoll I, Davatzikos C, An Y, Wu X, Shen D, Kraut M, et al. Longitudinal pattern of regional brain volume change differentiates normal aging from MCI. Neurology 2009;72(22):1906-13.

30) Chételat G, Landeau B, Eustache F, Mézenge F, Viader F, de la Sayette V, et al. Using voxel-based morphometry to map the structural changes associated with rapid conversion in MCI: A longitudinal MRI study. Neuroimage 2005;27(4):934-46.

31) Kleim JA, Jones TA. Principles of experience-dependent neural plasticity: Implications for rehabilitation after brain damage. J Speech Lang Hear Res 2008;51(1):S225-39.

32) Mick P, Kawachi I, Lin FR. The association between hearing loss and social isolation in older adults. Otolaryngol Head Neck Surg 2014;150(3):378-84.

33) Dawes P, Emsley R, Cruickshanks KJ, Moore DR, Fortnum H, Edmondson-Jones M, et al. Hearing loss and cognition: The role of hearing AIDS, social isolation and depression. PLoS One 2015; 10(3):e0119616.

34) Sugawara N, Sasaki A, Yasui-Furukori N, Kakehata S, Umeda T, Namba A, et al. Hearing impairment and cognitive function among a community-dwelling population in Japan. Ann Gen Psychiatry 2011;10(1):27.

35) Amieva H, Ouvrard C, Meillon C, Rullier L, Dartigues JF. Death, depression, disability, and dementia associated with self-reported hearing problems: A 25-year study. J Gerontol A Biol Sci Med Sci 
2018;73(10):1383-9.

36) Rutherford BR, Brewster K, Golub JS, Kim AH, Roose SP. Sensation and psychiatry: Linking age-related hearing loss to latelife depression and cognitive decline. Am J Psychiatry 2018;175(3): 215-24.

37) Kiely KM, Anstey KJ, Luszcz MA. Dual sensory loss and depressive symptoms: The importance of hearing, daily functioning, and activity engagement. Front Hum Neurosci 2013;7:837.

38) Cacioppo JT, Hawkley LC. Perceived social isolation and cognition. Trends Cogn Sci 2009;13(10):447-54.

39) Shankar A, Hamer M, McMunn A, Steptoe A. Social isolation and loneliness: Relationships with cognitive function during 4 years of follow-up in the English longitudinal study of ageing. Psychosom Med 2013;75(2):161-70

40) Lindenberger U, Baltes PB. Sensory functioning and intelligence in old age: A strong connection. Psychol Aging 1994;9(3):339-55.

41) Tavanai E, Mohammadkhani G. Role of antioxidants in prevention of age-related hearing loss: A review of literature. Eur Arch Otorhinolaryngol 2017;274(4):1821-34.

42) Snowdon DA, Greiner LH, Mortimer JA, Riley KP, Greiner PA, Markesbery WR. Brain infarction and the clinical expression of Alzheimer disease. The nun study. JAMA 1997;277(10):813-7.

43) Gopinath B, Schneider J, Rochtchina E, Leeder SR, Mitchell P. Association between age-related hearing loss and stroke in an older population. Stroke 2009;40(4):1496-8.

44) Gorelick PB, Scuteri A, Black SE, Decarli C, Greenberg SM, Iadecola $\mathrm{C}$, et al. Vascular contributions to cognitive impairment and dementia: A statement for healthcare professionals from the american heart association/american stroke association. Stroke 2011;42(9):2672-713.

45) De Silva TM, Faraci FM. Microvascular dysfunction and cognitive impairment. Cell Mol Neurobiol 2016;36(2):241-58.

46) Shi X. Physiopathology of the cochlear microcirculation. Hear Res 2011;282(1-2):10-24.

47) Lim SL, Gao Q, Nyunt MS, Gong L, Lunaria JB, Lim ML, et al. Vascular health indices and cognitive domain function: Singapore longitudinal ageing studies. J Alzheimers Dis 2016;50(1):27-40.

48) Uchida Y, Sugiura S, Ando F, Nakashima T, Shimokata H. Diabetes reduces auditory sensitivity in middle-aged listeners more than in elderly listeners: A population- based study of age-related hearing loss. Med Sci Monit 2010;16(7):PH63-8.

49) Kurniawan C, Westendorp RG, de Craen AJ, Gussekloo J, de Laat $\mathrm{J}$, van Exel E. Gene dose of apolipoprotein E and age-related hearing loss. Neurobiol Aging 2012;33(9):2230.e7-e12.

50) Mener DJ, Betz J, Yaffe K, Harris TB, Helzner EP, Satterfield S, et al. Apolipoprotein $\mathrm{E}$ allele and hearing thresholds in older adults. Am J Alzheimers Dis Other Demen 2016;31(1):34-9.

51) Dawes P, Platt H, Horan M, Ollier W, Munro K, Pendleton N, et al. No association between apolipoprotein $\mathrm{E}$ or N-Acetyltransferase 2 gene polymorphisms and age-related hearing loss. Laryngoscope 2015;125(1):E33-8.

52) Cobley JN, Fiorello ML, Bailey DM. 13 reasons why the brain is susceptible to oxidative stress. Redox Biol 2018;15:490-503.

53) Kamogashira T, Fujimoto C, Yamasoba T. Reactive oxygen species, apoptosis, and mitochondrial dysfunction in hearing loss. Biomed Res Int 2015;2015:617207.

54) Yamasoba T, Lin FR, Someya S, Kashio A, Sakamoto T, Kondo K. Current concepts in age-related hearing loss: Epidemiology and mechanistic pathways. Hear Res 2013;303:30-8.

55) Someya S, Prolla TA. Mitochondrial oxidative damage and apoptosis in age-related hearing loss. Mech Ageing Dev 2010;131(7-8):480-6.

56) Dupuis K, Pichora-Fuller MK, Chasteen AL, Marchuk V, Singh G, Smith SL. Effects of hearing and vision impairments on the montreal cognitive assessment. Neuropsychol Dev Cogn B Aging Neuropsychol
Cogn 2015;22(4):413-37.

57) Jorgensen LE, Palmer CV, Pratt S, Erickson KI, Moncrieff D. The effect of decreased audibility on MMSE performance: A measure commonly used for diagnosing dementia. J Am Acad Audiol 2016; 27(4):311-23.

58) Hill-Briggs F, Dial JG, Morere DA, Joyce A. Neuropsychological assessment of persons with physical disability, visual impairment or blindness, and hearing impairment or deafness. Arch Clin Neuropsychol 2007;22(3):389-404.

59) Gates GA, Cobb JL, Linn RT, Rees T, Wolf PA, D’Agostino RB. Central auditory dysfunction, cognitive dysfunction, and dementia in older people. Arch Otolaryngol Head Neck Surg 1996;122(2): 161-7.

60) Gates GA, Anderson ML, Feeney MP, McCurry SM, Larson EB. Central auditory dysfunction in older persons with memory impairment or Alzheimer dementia. Arch Otolaryngol Head Neck Surg 2008;134(7):771-7.

61) Gates GA, Anderson ML, McCurry SM, Feeney MP, Larson EB. Central auditory dysfunction as a harbinger of Alzheimer dementia. Arch Otolaryngol Head Neck Surg 2011;137(4):390-5.

62) Swords GM, Nguyen LT, Mudar RA, Llano DA. Auditory system dysfunction in Alzheimer disease and its prodromal states: A review. Ageing Res Rev 2018;44:49-59.

63) Panza F, Lozupone M, Sardone R, Battista P, Piccininni M, Dibello $\mathrm{V}$, et al. Sensorial frailty: Age-related hearing loss and the risk of cognitive impairment and dementia in later life. Ther Adv Chronic Dis 2018;10:2040622318811000.

64) Jayakody DMP, Friedland PL, Martins RN, Sohrabi HR. Impact of aging on the auditory system and related cognitive functions: A narrative review. Front Neurosci 2018;12:125.

65) Fried LP, Tangen CM, Walston J, Newman AB, Hirsch C, Gottdiener $\mathrm{J}$, et al. Frailty in older adults: Evidence for a phenotype. J Gerontol A Biol Sci Med Sci 2001;56(3):M146-56.

66) Chen DS, Betz J, Yaffe K, Ayonayon HN, Kritchevsky S, Martin $\mathrm{KR}$, et al. Association of hearing impairment with declines in physical functioning and the risk of disability in older adults. $\mathrm{J}$ Gerontol A Biol Sci Med Sci 2015;70(5):654-61.

67) Kamil RJ, Betz J, Powers BB, Pratt S, Kritchevsky S, Ayonayon $\mathrm{HN}$, et al. Association of hearing impairment with incident frailty and falls in older adults. J Aging Health 2016;28(4):644-60.

68) Gispen FE, Chen DS, Genther DJ, Lin FR. Association between hearing impairment and lower levels of physical activity in older adults. J Am Geriatr Soc 2014;62(8):1427-33.

69) Lin FR, Ferrucci L. Hearing loss and falls among older adults in the United States. Arch Intern Med 2012;172(4):369-71.

70) Avila-Funes JA, Amieva H, Barberger-Gateau P, Le Goff M, Raoux $\mathrm{N}$, Ritchie K, et al. Cognitive impairment improves the predictive validity of the phenotype of frailty for adverse health outcomes: The three-city study. J Am Geriatr Soc 2009;57(3):453-61.

71) Yassuda MS, Lopes A, Cachioni M, Falcao DV, Batistoni SS, Guimaraes VV, et al. Frailty criteria and cognitive performance are related: data from the FIBRA study in Ermelino Matarazzo, São Paulo, Brazil. J Nutr Health Aging 2012;16(1):55-61.

72) Solfrizzi V, Scafato E, Frisardi V, Seripa D, Logroscino G, Maggi $\mathrm{S}$, et al. Frailty syndrome and the risk of vascular dementia: The Italian longitudinal study on aging. Alzheimers Dement 2013;9(2): 113-22.

73) Panza F, Solfrizzi V, Logroscino G. Age-related hearing impairment-a risk factor and frailty marker for dementia and AD. Nat Rev Neurol 2015;11(3):166-75.

74) Ramage-Morin PL. Hearing difficulties and feelings of social isolation among Canadians aged 45 or older. Health Rep 2016; 27(11):3-12

75) Jayakody DMP, Almeida OP, Speelman CP, Bennett RJ, Moyle TC, 
Yiannos JM, et al. Association between speech and high-frequency hearing loss and depression, anxiety and stress in older adults. Maturitas 2018;110:86-91.

76) Panza F, Frisardi V, Capurso C, D'Introno A, Colacicco AM, Imbimbo BP, et al. Late-life depression, mild cognitive impairment, and dementia: Possible continuum? Am J Geriatr Psychiatry 2010; 18(2):98-116.

77) Frasure-Smith N, Lespérance F, Talajic M. Depression following myocardial infarction. Impact on 6-month survival. JAMA 1993; 270(15):1819-25.

78) Lee RS, Hermens DF, Porter MA, Redoblado-Hodge MA. A metaanalysis of cognitive deficits in first-episode major depressive disorder. J Affect Disord 2012;140(2):113-24.

79) Mezuk B, Edwards L, Lohman M, Choi M, Lapane K. Depression and frailty in later life: A synthetic review. Int J Geriatr Psychiatry 2012;27(9):879-92.

80) Mulrow CD, Aguilar C, Endicott JE, Tuley MR, Velez R, Charlip WS, et al. Quality-of-life changes and hearing impairment. A randomized trial. Ann Intern Med 1990;113(3):188-94.

81) Nguyen MF, Bonnefoy M, Adrait A, Gueugnon M, Petitot C, Collet
L, et al. Efficacy of hearing aids on the cognitive status of patients with Alzheimer's disease and hearing loss: A multicenter controlled randomized trial. J Alzheimers Dis 2017;58(1):123-37.

82) Mosnier I, Bebear JP, Marx M, Fraysse B, Truy E, Lina-Granade $\mathrm{G}$, et al. Improvement of cognitive function after cochlear implantation in elderly patients. JAMA Otolaryngol Head Neck Surg 2015; 141(5):442-50.

83) Lin FR, Albert M. Hearing loss and dementia - who is listening? Aging Ment Health 2014;18(6):671-3.

84) Di Nardo W, Anzivino R, Giannantonio S, Schinaia L, Paludetti G. The effects of cochlear implantation on quality of life in the elderly. Eur Arch Otorhinolaryngol 2014;271(1):65-73.

85) May A. Experience-dependent structural plasticity in the adult human brain. Trends Cogn Sci 2011;15(10):475-82.

86) Qiu C, Fratiglioni L. Aging without dementia is achievable: Current evidence from epidemiological research. J Alzheimers Dis 2018; 62(3):933-42.

87) Hsiao YH, Chang CH, Gean PW. Impact of social relationships on Alzheimer's memory impairment: mechanistic studies. J Biomed Sci 2018;25(1):3.

\section{정답 및 해설}

답 (5)

해 설 양측 인공와우 수술의 적응증이 되는 환아로 폐렴구균 예방접종을 시행해야 한다. 2 세 미만에서는 7 또는 13가의 폐렴구 균 결합백신을 사용할 수 있으며, 2세 이상에서는 폐렴구균 피막다당류백신(Pneumococcal polysaccharide vaccine, PPSV23)을 시행한다. temporal bone computed tomography(TBCT) 상 양측의 bony cochlear nerve canal(BCNC) stenosis가 관찰된다. MR을 시행하여 cochlear nerve의 존재 유무를 확인해볼 수 있다. BCNC stenosis의 경우 그렇지 않 은 경우에 비해 인공와우 수술후의 예후가 좋지 않음이 보고되고 있다. 청성뇌간 이식술의 고려대상이 될 수는 있으나, 아 직 청성뇌간이식술의 결과가 예측하기 어렵고, $\mathrm{BCNC}$ stenosis 환자에서 인공와우수술 후에도 비교적 좋은 결과를 보이는 경우도 있기 때문에 청성뇌간이식술을 우선적으로 고려하기는 어렵다. 